the other, the San Juan to the south, and then through a break in the coast Cordilleras to the west to the Pacific Ocean. The height of land separating the two systems scarcely reaches a height of $100 \mathrm{~m}$. This waterway is one of the strategic points in the geographical distribution of South American fishes and it is more than to be regretted that there is not a single record of a fresh-water fish from either of these rivers!

We are a little more fortunate about our knowledge of the fishes of the two sides of Panama, but are far from an exhaustive knowledge on the subject.

It would certainly be a disgrace not to make an exhaustive study of the fresh-water faunas of the two slopes before there is a chance of the artificial mingling of the two faunas. It ought to be urged upon congress to make provision for the biological survey of the canal zone if the president or the bureau of fisheries does not already possess authority to provide for it. The work should be undertaken at once.

For the biological survey of the Atrato-San Juan route we must depend upon private enterprise, and it is to be hoped that the means for so interesting and profitable work will not be lacking when the volunteers for the work are so numerous and willing.

On the preceding page I give the fishes recorded from the Chagres on the Atlantic and the Bayano and its tributary, the Mamoni, on the Pacific side of Panama, together with the distribution on the Atlantic or Pacific slope of species found in one of the rivers; but not in the other.

C. H. Eigenmann.

THE NUMBER OF YOUNG OF THE RED BAT. ${ }^{1}$

During the summer of 1904 four females of Lasiurus borealis with their young came under my observation, the data from which add to the information contained in a recent article on the subject by M. W. Lyon, Jr., in Proc. U. S. National Museum, Vol. 26, pp. $425-426$, recording the capture of a female of

\footnotetext{
${ }^{1}$ Presented before the Wisconsin Natural History Society, March, 1905.
}

this species with four nursing young, at Washington, D. C., June 18, 1902.

The Milwaukee specimens were all taken in the daytime clinging to the trunks of shade trees between the sidewalks and curbs in thickly populated residential parts of the city.

On July 14 a female with a single rather large young clinging to her was brought to me at the Public Museum. A few days later a female with three much smaller and less developed young was brought in after having been kept in captivity for a day or two until the mother had died. The young of this group were approximately the size of those figured by Mr. Lyon in the above-cited paper.

On July 23 a female with four larger young was brought to the museum. In this case the mother and young were alive. They had been confined for some hours in a pasteboard box and were quite restless. The half-grown young were clinging indiscriminately to each other and to the mother, who seemed fairly mobbed by her numerous progeny. A few days later I was shown another female with but a single young.

Of this bat Mr. Lyon cites observations of two having two young each, two having three and the instance under his own observation of one having four. Adding my own observations to this, we have the following records for number of cases and number of young: $2 \times 1,2 \times 2,3 \times 3$ and $2 \times 4$.

On the face of this tabulation it would appear that three is the more common number of young and that a single young is as frequent as four. However, it is not improbable that the females with single young may have lost others of their families either by death or by their accidentally becoming detached.

Two embryos were found in each of two females included in the above table and three embryos were found in two other included instances; consequently, it is certain that either two or three young may be born, but it does not appear equally certain that as small a number as one may occur at a birth, although that number appears to be common to genera other than Lasiurus and, as $\mathrm{Mr}$. Lyon states, probably Dasypterus. 
It is interesting to note, as pointed out by Mr. Lyon, that this unusually large number of young is coincident with the possession of four mammæ, whereas two is the number known in other bats.

That the mammæ of an animal should be as many as the normal number of young produced would appear to be a reasonable proposition, but that the normal number of young equals the number of mammæ is quite a different one, from which many exceptions will suggest themselves. For instance, the seals have four mammæ, yet one young is the rule and two the exception among the species with which I am familiar.

The fact of an increased number of mammæ in these bats correlates well with the observed fact of an unusual number of young, and I would be pleased to know of farther observations that may tend to establish what is the average number.

Public Museum,- Milwaukee.

\section{BOTANICAL NOTES.}

PLANT CELL STUDIES.

UNDER the title of 'Studies on the Plant Cell' Dr. B. M. Davis is bringing together in a series of articles published in the American Naturalist (May, 1904, to April, 1905) what is known of the structure and activities of the plant cell. This is necessary because of the inadequacy and incompleteness of the accounts to be found in even the most recent botanical text-books. The author hopes, also, to 'help to change an attitude toward investigations on the plant cell that is unfortunately too prevalent among botanists,' $i$. e., to regard - cytology as a very special field with an elaborate technique beyond the capabilities of the average botanist. In carrying out this plan the author divides the subject into six sections, viz.: (I.) The structure of the plant cell; (II.) the activities of the plant cell; (III.) highly specialized plant cells and their peculiarities; (IV.) cell unions and nuclear fusions in plants; (V.) cell activities at critical periods of ontogeny in plants; (VI.) comparative morphology and physiology of the plant cell. The treatment under each of these heads, as far as published, is very satisfactory, and the author has certainly succeeded in making a most lucid statement in regard to every point. Where necessary he does not hesitate to indicate our lack of knowledge in regard to any structure, as when he discusses the nucleolus, and says that its substance is not well understood. Yet he does not refrain from stating his belief where it may be an aid to a clearer general understanding of the subject, as in the discussion of the pyrenoid, which he conjectures will prove to be a metabolic center of the chromatophore which is more or less prominent according to conditions of nutrition, whose most conspicuous activity is ' the formation of starch by the direct transformation of portions of its substance.'

In the discussion of direct-cell division the author suggests the possibility that this may be a reversion to early ancestral conditions, mitosis being regarded as phylogenetically a later process. With regard to centrospheres the author recognizes their existence in thallophytes only. As to the theory of the permanence of the chromosome Dr. Davis says 'it can hardly be said that the doctrine is established.'

In passing we note that the author regards the plasmodium of the slime molds as a coenocyte, and further that coenocytes of all kinds are to be regarded as multinucleate cells, and therefore units, instead of compound structures whose cells have not become separated by walls.

In the last article (IV.), devoted to cell unions and nuclear fusions, the author draws a sharp line of distinction between those which are sexual and those which are asexual. Under the latter (asexual) he includes the fusions of amoeboid cells to form plasmodia, the nuclear fusions in the teleutospores of smuts and rusts, and the nuclear fusions connected with 'double fertilization.' The remaining articles of this instructive publication will be looked for with keen interest.

\section{LEAF INTUMESCENCES.}

In the Sixteenth Annual Report of the Missouri Botanical Garden Dr. Hermann von Schrenk contributes an article on the interesting problem of the cause of intumescences 